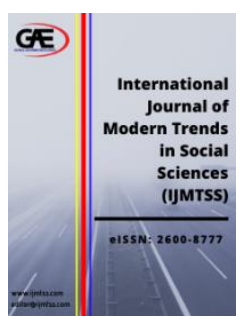

\author{
INTERNATIONAL JOURNAL OF \\ MODERN TRENDS IN \\ SOCIAL SCIENCES \\ (IJMTSS) \\ wWw.ijmtss.com
}

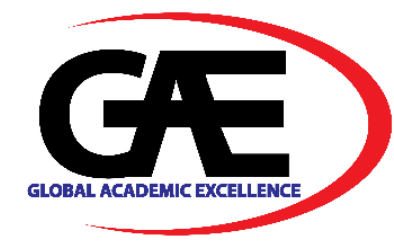

\title{
CUSTOMER SATISFACTION OF SERVICES PROVIDED BY FRESH FRUIT BUNCH (FFB) COLLECTION CENTERS
}

\author{
Nazirah Che Jaafar ${ }^{1 *}$, Zaki Aman ${ }^{2}$ \\ 1 Smallholders Development Research Division, Malaysian Palm Oil Board, Malaysia \\ Email: nazirah@mpob.gov.my \\ 2 Smallholders Development Research Division, Malaysian Palm Oil Board, Malaysia \\ Email: zaki@mpob.gov.my \\ * Corresponding Author
}

\section{Article Info:}

Article history:

Received date: 30.10 .2020

Revised date: 08.11.2020

Accepted date: 18.11 .2020

Published date: 03.12.2020

To cite this document:

Che Jaafar, N., \& Aman, Z. (2020). Customer Satisfaction of Services Provided by Fresh Fruit Bunch (FFB) Collection Centres. International Journal of Modern Trends in Social Sciences, 3 (14), 72-77.

DOI: $10.35631 / \mathrm{IJMTSS} .314006$

This work is licensed under $\underline{\mathrm{CC} B Y} 4.0$ (c)

\begin{abstract}
:
Koperasi Penanam Sawit Mampan (KPSM) or in English known as Sustainable Oil Palm Growers Cooperative has been established since 2010. KPSM is an alternative model that can meet the needs of oil palm independent smallholders (ISH) and play a role in helping to improve community development. The main objective of this cooperative is to improve the income of independent oil palm smallholders. The objective of the implementation of the study was to identify the customer satisfaction level towards the FFB sales service operated by KPSM. This study involved independent oil palm smallholders who sent fresh fruit bunches (FFB) to KPSM cooperative collection centres. Questionnaires were distributed to 330 respondents and sampling was carried out by random sampling. The data were analysed using SPSS to analyse the quantitative data, which covered frequencies and percentages. The study findings indicated that the majority of respondents were KPSM members (61.9\%), who cultivated palm full time, $(69.6 \%)$ with an average age of 46 years old. The study also proved that the smallholders' satisfaction level who received the services provided by the cooperative, was very good. However, customer satisfaction in terms of infrastructure amenities was less satisfactory, and the findings from this study were hoped to be able to assist various parties to improve the quality of services provided by KPSM.
\end{abstract}

Keywords:

Cooperative, Satisfaction, Customer

\section{Introduction}

Independent oil palm smallholders (ISH) was an important sector in the national oil palm industry, as they contributed a total of $16.3 \%$ of the total area of palm plantation in Malaysia 


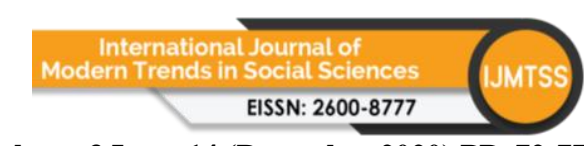

Volume 3 Issue 14 (December 2020) PP. 72-77

DOI 10.35631/IJMTSS.314006

(Kushairi et al., 2019). The independent oil palm smallholders' sector was a small-scale producing entity. The ISH sector is a small-scale producer entity with a low average area per hectare of smallholders in Malaysia is just less than 4 hectares per person (Rahman et al., 2008). The limited average size of farm land, the scattered geographical locations leads to high production costs. Most of the ISH are second or third generation and therefore, they still lack the knowledge and experience of farm management which, when combined with insufficient exposure to good agricultural farming practice were the main factors contributing to the low FFB production and income.

The problem faced by the ISH could be overcome by grouping them under an organisation. Under the Eleventh Malaysia Plan (RMKe-11), the government has taken an initiative to empower these smallholders under a cooperative, aptly named as Sustainable Oil Palm Growers Cooperative (KPSM). The objective of the cooperative was to empower smallholders so that they are able to manage their oil palm plantataion for maximum benefit. To address the issues faced by the ISH, KPSM plays the key roles of implementing the business of fresh fruit bunch (FFB) sales direct to the factories, discussing problems faced by ISH, as the mediator with the government/agency and providing agricultural input, such as fertilisers. Various aids from the government have been channelled to KPSM to enable the cooperative to operate and to be able to assist smallholders and surrounding communities. As at December 2019, a total of $62 \mathrm{KPSM}$ have been established and 41 numbers of KPSM collection centres have commenced smallholders FFB business with a total sale of 195,437.67 MT.

Customer satisfaction was the key to any business (Mustafa, 2007), in which the satisfaction of receiving a service would be assessed by customers. To make a business/service provided by a cooperative to remain competitive, customer satisfaction towards the quality of services in the cooperative should achieve a satisfactory level.

According to Aidil (2008), Customer Satisfaction was one of the business terms which meant to measure how far a product or service provided by the organisation meet the customer expectation, namely Customer Expectation, or in other words, customer satisfaction was the part which showed the wants, needs, and expectations of the customer that needed to be achieved or fulfilled to create customer loyalty towards the products or services provided.

Presently, various measurement instruments to measure the quality of services to meet the customer satisfaction (Ramli et al., 2009) were available. Among the instruments used included SERVQUAL. Assessment using the SERVQUAL concept would measure the quality of services based on five dimensions, which were the dimensions, highly assessed by customers in meeting satisfaction level towards any service, namely Reliability, Assurance, Tangibles, Empathy, and Responsiveness (Mohd Faiz et al., 2011).

The five important dimensions, namely i) tangibles, the physically seen aspects, such as equipment and individual on duty; ii) reliability, the ability to have an assumed ability; iii) responsiveness such as the desire to respond, to want, or to need; iv) assurance was the personal ability to create trust and peace of mind to customers; and v) empathy referred to the personal need for observation and care for each customer.

This study was implemented to determine the level of customer satisfaction of services provided by fresh fruit bunch (FFB) collection centers. Furthermore, the demographics of the customers were also investigated.

Copyright (C) GLOBAL ACADEMIC EXCELLENCE (M) SDN BHD - All rights reserved 


\section{Methodology}

This study used the quantitative approach. Data collection was carried out by structured questionnaires and applied descriptive method to describe the customer satisfaction towards KPSM. The population of this study consisted of smallholders who had received services from KPSM in Malaysia, which totalled 2,426 smallholders. A random sampling technique was applied with a total number of 330 samples. The number of samples was based on Krejcie and Morgan (1970).

Distributed questionnaires would consist of two main parts, namely part A and B. The part A constituted questions covering respondent demographic data, whereas part B consisted of questions pertaining to customer satisfaction based on the assurance, responsiveness, and tangible dimensions. In this study, the researchers focused on these three dimensions first since they tally with the services provided by KPSM weighing centres. Likert scale was used to obtain the respondents' agreement scale based on five levels, namely 1 - less satisfactory, 2 satisfactory, 3 - good, 4 - very good, and 5 - excellent.

\section{Results and Discussion}

Table 1 indicates that the majority of KPSM customers were full time oil palm smallholders (69.6\%). 30.4\% respondents cultivated oil palm part time. In terms of age, four age variations were specified in the questionnaires. The average age of respondents was 46 years. Most respondents were older than 50 years old $(39.7 \%)$. These facts were supported by several studies which proved that the average age of smallholders in Malaysia was in the range of 50 60 years (Sheilyza et al., 2018; Nursuhana et al., 2018 and Mohd Haidhar et al., 2019). Whereas, as for KPSM membership, the majority of respondents were KPSM members (61.9\%), and only $38.1 \%$ respondents were non-members, who also used the FFB sales service implemented by KPSM. Study from Nazirah et al., (2016) also revealed that majority of oil palm smallholders not a member in other cooperatives.

Table 1: The Demographic Profiles of Respondents

\begin{tabular}{llcc}
\hline Features & & Frequency & Percentage $(\%)$ \\
\hline Age & & 83 & 24.3 \\
(mean $=45.93)$ & $<35$ years old & 123 & 36.0 \\
\cline { 2 - 4 } & $36-50$ years old & 88 & 25.7 \\
\cline { 2 - 4 } & $51-60$ years old & 48 & 14.0 \\
\cline { 2 - 4 } & $>60$ years old & 233 & 69.6 \\
\hline \multirow{2}{*}{ Smallholders } & Full time & 102 & 30.4 \\
\cline { 2 - 4 } & Part time & 206 & 61.9 \\
\hline \multirow{2}{*}{ KPSM Membership } & Member & 127 & 38.1 \\
\cline { 2 - 4 } & Non-member & & \\
\hline
\end{tabular}

Table 2 indicates the dimensions of customer satisfaction towards the services provided by KPSM. Customers assessed an organisation performance mainly based on interaction and worker's friendly and caring treatment towards customers (Chaoprasert and Elsey, 2004). The highest mean score was contributed by the statement that services provided by KPSM staff was customer friendly (3.98). The respondents also agreed that KPSM staff provided very good services to them (3.97). 
Table 2: Satisfaction Towards Services Provided by KPSM

\begin{tabular}{|c|c|c|c|c|c|c|c|c|}
\hline \multirow{2}{*}{\multicolumn{2}{|c|}{ Item }} & \multicolumn{5}{|c|}{ Scale of Satisfaction* } & \multirow{3}{*}{$\begin{array}{c}\text { Mean } \\
3.75\end{array}$} & \multirow{3}{*}{$\begin{array}{c}\text { S.D } \\
1.035\end{array}$} \\
\hline & & \multirow{2}{*}{$\begin{array}{c}\mathbf{1} \\
10 \\
2.6\end{array}$} & \multirow{2}{*}{$\begin{array}{c}2 \\
31 \\
8.2\end{array}$} & \multirow{2}{*}{$\begin{array}{c}\mathbf{3} \\
109 \\
28.8\end{array}$} & \multirow{2}{*}{$\begin{array}{c}4 \\
123 \\
32.5\end{array}$} & \multirow{2}{*}{$\begin{array}{c}\mathbf{5} \\
105 \\
27.8\end{array}$} & & \\
\hline 1. Meets customer's needs & $\begin{array}{l}\mathrm{n} \\
\%\end{array}$ & & & & & & & \\
\hline $\begin{array}{l}\text { 2. Information } \\
\text { communicated properly }\end{array}$ & $\begin{array}{l}\mathrm{n} \\
\%\end{array}$ & $\begin{array}{c}5 \\
1.3\end{array}$ & $\begin{array}{l}28 \\
7.3\end{array}$ & $\begin{array}{c}94 \\
24.7\end{array}$ & $\begin{array}{r}152 \\
39.9\end{array}$ & $\begin{array}{r}102 \\
26.8\end{array}$ & 3.83 & .949 \\
\hline 3. Fast and responsive & $\begin{array}{l}\mathrm{n} \\
\%\end{array}$ & $\begin{array}{c}6 \\
1.6\end{array}$ & $\begin{array}{l}32 \\
8.5\end{array}$ & $\begin{array}{c}87 \\
23.0\end{array}$ & $\begin{array}{l}137 \\
36.2\end{array}$ & $\begin{array}{r}116 \\
30.7\end{array}$ & 3.86 & 1.001 \\
\hline 4. Easily reachable & $\begin{array}{l}\mathrm{n} \\
\%\end{array}$ & $\begin{array}{l}17 \\
4.5 \\
\end{array}$ & $\begin{array}{l}28 \\
7.4\end{array}$ & $\begin{array}{c}82 \\
21.6 \\
\end{array}$ & $\begin{array}{r}130 \\
34.3\end{array}$ & $\begin{array}{r}122 \\
32.2 \\
\end{array}$ & 3.82 & 1.100 \\
\hline 5. Customer friendly & $\begin{array}{l}\mathrm{n} \\
\%\end{array}$ & $\begin{array}{c}8 \\
2.1 \\
\end{array}$ & $\begin{array}{l}26 \\
68 \\
\end{array}$ & $\begin{array}{c}71 \\
18.7 \\
\end{array}$ & $\begin{array}{r}135 \\
35.5 \\
\end{array}$ & $\begin{array}{r}140 \\
36.8 \\
\end{array}$ & 3.98 & 1.010 \\
\hline 6. Good work performance & $\begin{array}{l}\mathrm{n} \\
\%\end{array}$ & $\begin{array}{l}10 \\
2.6\end{array}$ & $\begin{array}{l}16 \\
4.2\end{array}$ & $\begin{array}{c}85 \\
22.3\end{array}$ & $\begin{array}{r}134 \\
35.2\end{array}$ & $\begin{array}{r}136 \\
35.7\end{array}$ & 3.97 & .993 \\
\hline 7. Sufficient facilities & $\begin{array}{l}\mathrm{n} \\
\%\end{array}$ & $\begin{array}{l}17 \\
4.7\end{array}$ & $\begin{array}{c}48 \\
13.3\end{array}$ & $\begin{array}{c}93 \\
25.7\end{array}$ & $\begin{array}{l}117 \\
32.3\end{array}$ & $\begin{array}{c}87 \\
24.0\end{array}$ & 3.58 & 1.129 \\
\hline $\begin{array}{l}\text { 8. Cleanliness of collection } \\
\text { centres }\end{array}$ & $\begin{array}{l}\mathrm{n} \\
\%\end{array}$ & $\begin{array}{c}6 \\
1.6\end{array}$ & $\begin{array}{l}35 \\
9.5\end{array}$ & $\begin{array}{c}91 \\
24.8\end{array}$ & $\begin{array}{c}141 \\
38.4\end{array}$ & $\begin{array}{c}94 \\
25.6\end{array}$ & 3.77 & .991 \\
\hline 9. Comfort & $\begin{array}{l}\mathrm{n} \\
\%\end{array}$ & $\begin{array}{r}14 \\
3.9\end{array}$ & $\begin{array}{l}32 \\
8.8\end{array}$ & $\begin{array}{c}94 \\
25.9\end{array}$ & $\begin{array}{r}126 \\
34.7 \\
\end{array}$ & $\begin{array}{c}97 \\
26.7\end{array}$ & 3.72 & 1.072 \\
\hline
\end{tabular}

Note *: 1 - Less Satisfactory, 2- Satisfactory, 3 - Good, 4 - Very good, 5 - Excellent

This study also found that, even though the overall dimension mean score achieved more than 3.5, the mean score for facilities at the collection centres recorded the lowest score (3.58), which indicated that the facilities provided by KPSM at the collection centres were still insufficient for the smooth operation of the collection centres. Whereas, the comfort of KPSM collection centres recorded the second lowest mean score (3.72). This showed that the facilities at the collection centres were still insufficient and not meeting customer requirements.

Meanwhile, the service dimension provided by the cooperatives fulfilled the customer requirements, which recorded a mean score of 3.75. Respondents agreed that cooperatives were able to communicate information effectively and fast, and to give feed backs to the customers of weighing centres.

Table 3 indicates the respondents' customer satisfaction level. Overall, the customer satisfaction level towards KPSM was very good, with a recorded mean score of 3.85. However, $10 \%$ of respondents recorded their satisfaction level towards KPSM only as satisfactory. Customers were important assets to any business. Othaman (2017) in his study states that customers would be more confident and satisfied if cooperatives could provide services that they need. Hossain and Leo (2009) also state that high quality services created loyalty and customer satisfaction. Apart from that, quality services helped increase sales and reduce costs to attract more customers. 
Table 3: Customer Satisfaction Level

\begin{tabular}{ccccccccc}
\hline Item & \multicolumn{1}{c}{} & $\mathbf{1}$ & $\mathbf{2}$ & $\mathbf{3}$ & $\mathbf{4}$ & $\mathbf{5}$ & Mean & S.D \\
\hline 1. Overall customer & $\mathrm{n}$ & 1 & 30 & 85 & 140 & 110 & 3.85 & .998 \\
satisfaction level & $\%$ & 1.9 & 8.1 & 22.8 & 37.6 & 29.6 & & \\
\hline
\end{tabular}

Note *: 1 - Less Satisfactory, 2- Satisfactory, 3 - Good, 4 - Very good, 5 - Excellent

\section{Conclusion}

Generally, this study has provided valuable knowledge to cooperatives in understanding customer satisfaction level towards the services provided by the cooperatives. Overall, the smallholders' satisfaction level, who received services provided by cooperatives was very good. This study also showed that staff hospitality quality, and fast and clear communication of information were very good. Apart from that, this study has shown that the infrastructures of the cooperative weighing centres were less satisfactory and could help various parties to improve the quality of services provided by cooperatives.

\section{References}

Aidil, S. A. K. (2008). Customer Satisfaction Model for E-Runcit Website. Masters Project. Skudai: University of Technology, Malaysia. Retrieved on $5^{\text {th }}$ December, 2019 from http://eprints.utm.my/id/eprint/9526/1/AidilSurayaMFC2008.pdf.

Azman, I., Ain, H., Khairuman, H., Nur Hanani, M., Norhazifah, S., \& Balu, N. (2016). Increased Productivity and Revenues through Efficient Farm Land Management.

2016 National Palm Smallholders Conference Proceeding, 11 - 12 October 2016, Hotel Kinta Riverfront, Ipoh, Perak.

Chaoprasert, C., \& Elsey, B. (2004). Service Quality Improvement in Thai Retail Banking and Its Management Implications. ABAC Journal, 24(1), 47-66.

Hossain, M., \& Leo, S. (2009). Customer perception on service quality in retail banking in Middle East: the case of Qatar. International Journal of Islamic and Middle Eastern Finance and Management, 2(4), 338-350.

Krejcie, R.V., \& Morgan, D.W. (1970). Determining sampel size of research activities. Educational and Psychological Measurement 30: 607-610.

Kushairi, A., Ong-Abdullah, M., Nambiappan, B., Hishamuddin, E., Bidin, M.N.I.Z., Ghazali, R., Subramaniam, V., Sundram, S., \& Parveez, G.K.A. (2019). Oil palm economic performance in Malaysia and R\&D Progress in 2018. Journal of Oil Palm Research 31(2), pp.165-194.

Mohd Faiz, M.N., \& Lee, M.F. (2011). Customer Satisfaction Towards Quality of Services in the Faculty of Technical Education in terms of Amenities and Facilities. Retrieved on $3^{\text {rd }}$ December, 2019 from eprints.uthm.edu.my/eprint/3.pdf.

Mohd Haidhar, A.H., Ainul, S.S., \& Ramle, M. (2019). Impact of Economic Stimulus Pachage II Incentive Scheme (PRE2) on Yield and Income of Oil Palm Smallholders in Peninsular Malaysia. Oil Palm Industry Economic Journal 19 (1): 35 - 42.

Mustafa, Z. (2007). Quality Attribute Classification to Improve Customer Satisfaction. Journal of Quality Measurement and Analysis, 3(1), p. 149-159.

Nazirah, C.J., Ramli, A., Hamdan, A.B., Kamalrudin, M.S., Siti, M.A., Nur, H.M. (2015). Perception of Independent Oil Palm Smallholders on Sustainable Oil Palm Growers Cooperatives. MPOB 196th Viva Committee Meeting, Viva No. 696/2015 (02). 
Nursuhana, D., Nur Hanani, M., Hasmiza, D., Sheilyza, M.I., Parthiban, K., Mohamad, A.J., Amran, A., Khairul, A., \& Tan, S.P. (2018). Penggunaan Cantas di Kalangan Pelebun Kecil Sawit. Prosiding Persidangan Kebangsaan Pekebun Kecil 2018: 84 - 89.

Othaman, N. (2017). Management of Service Quality Affect Customer Satisfaction in Takaful Companies. Study of Customers of Takaful Companies in Penang. Degree in Management, University of Science, Malaysia, Penang. Retrieved on 29 January, 2020 from https://www.academia.edu/37277859/.

Rahman, A.K.A., Abdullah, R., Shariff, F.M., \& Simeh, M.A. (2008). The Malaysian Palm Oil Supply Chain: The Role of the Independent Smallholder. Palm Oil Industry Economic Journal Vol. 8(2)/2008.

Ramli, N., Chai, S.F., \& Idris, F. (2009). Study of Customer Satisfaction towards Public University Library Services in Malaysia. Journal of Management 28: 23-43.

Sheilyza, M.I., \& Zulkifli, A.M. (2018). Kajian Pengetahuan, Sikap dan Amalan Pertanian Baik (GAP) Pekebun Kecil Persendirian dalam Pengurusan Sawit. Prosiding Persidangan Kebangsaan Pekebun Kecil 2018: 57 - 61. 